\title{
THE LEGAL RESPONSE TO PRIZE FIGHTING IN NINETEENTH CENTURY ENGLAND AND AMERICA
}

\author{
Jack Anderson, School of Law, Queen's University Belfast
}

\section{Introduction}

In the spring of 1888, champion-pugilist, John L. Sullivan, was nearing the end of a year-long promotional tour of Britain and Ireland. Sullivan had been bare fisted prize fighting's undisputed champion for six years. As was the practice, he had rarely defended his title in a competitive setting, content to fight gloved exhibitions under the Queensberry Rules. However, in January 1888, Sullivan agreed to fight a leading English fighter, Charlie Mitchell. This article will highlight that by the 1880s the English legal authorities had, as a result of half a century of dedicated legal intervention, almost eradicated prize fighting from the jurisdiction and, unsurprisingly, on March 2, 1888, Mitchell found himself peremptorily bound to the peace for over two hundred pounds. The fight, which ended in a draw, had to take place eight days later on the estate grounds of Baron Alphonse Rothschild near Chantilly, just north of Paris.

As the pugilists and their immediate entourage left the Rothschild estate, French police arrested them. Sullivan spent a night in jail but subsequently skipped bail and fled to America. He was later sentenced in absentia to three days in prison and a fine of one thousand francs. As Sullivan returned home, it was surely evident to him that the days of the bare knuckle fight were drawing to a close. The risk of injury, the considerable obstacles in arranging and holding prizefights as well as increased legal surveillance were threatening the very existence of the sport. In addition, it was increasingly clear that whatever "stake" fighters such as Sullivan won in a bare knuckle bout, they would end up spending most of it in an attempt to stay out of prison.

Queensberry-regulated bouts now became an attractive proposition for Sullivan. Gloved bouts attracted lower levels of physical risk, they decreased a fighter's legal exposure and they increased his commercial capacity by permitting him to fight more often and more openly. Consequently, it is the contention of this article that Sullivan, whose reign is generally held to mark the beginning of the modern heavyweight championship and whose influence on the sport goes beyond that, bridged the (legal) gap between the bare fisted prizefight and the gloved bout. More fundamentally, it is also suggested that, in a pattern first established in England, the criminal law of the United States forced fighters to forego bare fisted fights under the London Prize Ring Rules and manipulated them into adopting the Queensberry Rules. It is further submitted that, in a typical example of nineteenth-century social engineering, once the English and American authorities became satisfied that the activity in question was adequately regulated and codified, the criminal law was seen to retreat.

In strictly legal terms, the legitimising equation that emerged can be understood as follows: boxing, as regulated by the Queensberry Rules or 
some statutory derivation thereof, was not prize fighting; it did not incite social disturbance nor act as a threat to general public morality; it no longer required participants to fight to a standstill nor could it be considered unacceptably dangerous. The historical context of that "equation" is now examined to the point where it is argued that the induced evolution of prize fighting into modern boxing provides a provocative insight into some of the hitherto undervalued socio-legal forces at play in England and American during the nineteenth century.

\section{Regency Boxiana}

In his treatise Pleas of the Crown (1803), Sir Edward East viewed the legal repercussions of fatal accidents in sport as follows:

"If death ensues from such as are innocent and allowable, the case will fall within the rule of excusable homicide: but if the sport be unlawful in itself, or productive of danger, riot or disorder from the occasion, so as to endanger peace, and death ensues; the party killing is guilty of manslaughter."

Activities that East deemed "innocent and allowable" and not unlawful included the "manly sports and exercises that tend to give strength and activity in the use of arms" such as "playing at cudgels, or foils or wrestling". These activities, according to East, were entered into merely as private recreations among friends "though doubtless it cannot be said that such exercises are altogether free of danger yet they are very rarely attended with fatal consequences; and each party has friendly warning to be on his guard."

\section{East continued:}

". . . [b]ut the latitude given to manly exercises of the nature above described, when conducted merely as diversions among friends, must not be extended to legalise prize fightings, public boxing matches, and the like, which are exhibited for the sake of lucre and are calculated to draw together a number of idle and disorderly people."

East must have been aware of the popularity of the sport of prize fighting among his contemporaries and he would have been in his early twenties when Daniel Mendoza fought Richard Humphries in a series of celebrated bouts attended by thousands of commoners, members of the "Fancy" and the Prince of Wales. ${ }^{4}$ The sport clearly appealed to all elements of society. In July 1821, when the Regency reached its zenith with the coronation of George IV, prize fighting was prominently represented with a number of fighters acting as pageboys during the ceremony. They were charged with keeping order during proceedings at Westminster Abbey and, by all

1 East P.C. 268.

ibid.

3 ibid., at 270.

4 Contemporary reports of these and other fights can be found in J. Ford's reproduction of Boxiana, or, Sketches of Ancient and Modern Pugilism by Pierce Egan (1976). See also J. Ford, Prizefighting: The Age of Regency Boxiana, 17871824 (1971). 
accounts, they fulfilled their role admirably even when Caroline, the King's estranged wife, reacted melodramatically to His Majesty's strict orders to refuse her entry.

Gorn attempts to explain this social phenomenon by suggesting:

"Perhaps the aggressive masculinity of the ring was a defensive reaction for men of an old upper class whose relative power and wealth - the very basis of their patriarchal prerogatives - were declining. Prizefights and other popular recreations momentarily re-established elite authority among the masses. They allowed gentlemen at once to mingle with the multitudes, cementing the loyalty of their social inferiors, but simultaneously to distance themselves through displays of wealth and largesse." 5

The patronage of the "Fancy" ensured that the sport had a sound financial footing. More importantly, their attendance also discouraged the authorities from intervening in any meaningful way with the holding of prizefights. Popular enthusiasm for prize fighting notwithstanding, the law's institutional writers remained unconvinced. According to East, the nature of a professional prizefight was such that it must be seen to corrupt the sporting intention of the fighters: "For in such cases, the intention of the parties is not innocent in itself each being careless of what hurt may be given, provided that the promised award or applause be obtained." 6

In East's opinion, the consent of the participants had to be considered vitiated by their overwhelming resolve to obtain monetary reward. There is an element of paternalism in the belief that fighters, weak in the sight of money and applause, had to be prevented from recklessly exposing themselves to harm. Nevertheless, that stance was analogous to the English courts' well-established view that consent was no defence to killing in a duel: so as the consent of duellists was seen as false and coerced upon "the punctilio of what swordsmen falsely call honour"; prizefighters were seen to recklessly compromise their bodily integrity, and that of their opponent, for monetary reward. ${ }^{7}$

However, it would not be until the mid-nineteenth century, when increased policing and a shift in public attitudes - from the dilettante roughness of the Regency period to the disciplined utilitarianism of the early Victorian period - that there would be a marked increase in the rates of conviction against duellists. ${ }^{8}$ Kernan's summary of the abandonment of the "unhappy custom" of duelling also reflects the Fancy's parallel abandonment of prize fighting in the 1830s:

5 E. Gorn, The Manly Art: Bare Knuckle Prize Fighting in America (1989), p.27.

61 East P.C. 270.

7 Fost. 296. See also $R$ v Mawgridge (1706) 17 St. Tr. 57, $R$ v Oneby (1726) 17 St. Tr. 29, $R$ v Rice (1803) 3 East 581, 102 E.R. 719 and J. Horder, "The Duel and the English Law of Homicide" (1992) 12 O.J.L.S. 12.

$8 R$ v Young and Webber (1838) 8 Car \& P 644, 173 ER 655, $R$ v Cuddy (1843) 1 Car \& K 210, 174 ER 779 and D. Andrew, "The Code of Honour and its Critics: The Opposition to Duelling in England, 1700-1850” (1980) 5 Social History 409. 
"For a long time a rooted instinct made Toryism feel that to abandon the time-honoured right to private combat would be perilous surrender...But the Reform Act of 1832 meant defeat by the better-off middle classes, and it was soon followed by the rampant Chartism of the workers. It might well seem that an outpost of aristocracy like duelling was no longer a bulwark, but a source of weakness, a hindrance to the closing ranks among all the propertied which the times so loudly called for." 9

In short, prize fighting became exposed, in a legal sense, as the support of its former patrons ebbed away. Prize fighting's vulnerability was aggravated by the fact that, in an organisational sense, the sport imploded in the 1830s. Safety standards slipped dramatically. The historical authority of the Broughton Rules, then almost a century old, was fading. The Broughton Rules were named after the leading English prizefighter of the eighteenth century. In 1741, John Broughton fought the inexperienced George Stevenson of Hull. Over the course of the forty-minute fight, Stevenson received a severe hammering with a blow to the heart forcing his final collapse. Stevenson died a number of weeks later. Apparently, Broughton was so affected by the fatality that he used his status to promote the sport's first set of uniform rules, published in $1743 .^{10}$

Boxing at that time was only vaguely related to the sport we know today. Wrestling and grappling were acceptable tactics as was eye-gouging and "purring", which was the raking of a spiked boot across a fallen man. There was no such thing as a formal roped-off ring and often the only preparation was a chalk mark scratched on the ground. If a competitor could not bring themselves up to that scratch (as assisted by his seconds), he would then be deemed defeated. The Broughton Rules introduced three major innovations. Firstly, there was a requirement that a "square of a yard" be chalked in the centre of the ring. When a fighter was knocked, his seconds had thirty seconds to get him into position on one side of the square, facing his opponent. In effect, this was the first time that bouts were divided into rounds since each knockdown ended the fighting for at least thirty seconds. The Broughton Rules also introduced the concept of independent umpiring. Finally, though wrestling holds were permitted, a number of safety initiatives were introduced with Rule VII stating: "That no person is to hit his Adversary when he is down... a man on his knees is to be reckoned down."

The Broughton Rules did little to rid the sport of its occasional and sickening excesses. For example, while fighters could avail of a thirty-second "break" on knockdown, there was still no limit on the duration of the fight as a whole. Neither was there any weight classification, and fighters with significantly different physiques could be pitted against each other. By the 1830s, the sport was losing further credibility: "much was allowed pass that it earlier days would have meant disqualification - head butting, hitting a man who was down on one knee, falling with knees in his throat or groin and even the equivalent of rugby tackles."11 In addition, and as driven by betting

9 V.G. Kiernan, The Duel in European History (1989), p.125.

10 B. Mee, Bare Fists: The History of Bare-Knuckle Fighting (2001), p.13.

11 D. Brailsford, Bareknuckles: A Social History of Prizefighting (1988), p.89. 
patterns, fighters' seconds would often continue to drag clearly exhausted fighters up to scratch in the hope that their charge might make an "active recovery". In 1829, this practice had seen one group of seconds sentenced to transportation for life, there being, according to the trial judge, "no excuse whatsoever" for permitting the deceased to continue after he was gravely injured. ${ }^{12}$ Furthermore, the death of Simon Byrne in similar circumstances, during a championship fight against James Burke in London on May 30, 1833, had a hugely detrimental impact on the sport, attracting enhanced police concern. ${ }^{13}$

The Annual Register of 1838 notes that four men, while acting as seconds, were convicted of manslaughter having failed to prevent their clearly injured fighter from continuing. ${ }^{14}$ The trial overshadowed the introduction of the London Prize Ring Rules, which set out to update the Broughton Rules. The most notable safety rule was that a knockdown would mark the end of a round and on receiving a thirty-second break a fighter would then be given eight seconds to come up to scratch unaided. In retrospect, 1838 was a pivotal year for the sport of prize fighting in England. Although the London Prize Ring Rules gave the sport a sheen of progressiveness, all previous attempts to administer the sport had failed. Despite being founded by leading ex-pugilists, self-regulating agencies such as the Pugilistic Club established in 1814 and the Fair Play Club in 1825, had quickly lost control of and credibility within the sport.

Moreover, emboldened by the exoneration of the Metropolitan Police in the inquiry into the Coldbath fields disturbances of 1833, the nascent police forces began to target prize fighting events. Reformers such as Patrick Colquhoun urged the police to broaden their remit from crimes against the person and property to the investigation of moral and social evils. The existing laws on drunkenness, prostitution, vagrancy, Sabbath breaking, gambling and cruel sports, according to social reformers, needed to be enforced with greater rigour. ${ }^{15}$ A prizefight incorporated many of these social evils and were known as events hosted and sponsored by publicans. ${ }^{16}$ Prize fighting was also seen to brutalise the masses with its easy acceptance of violence on display. It is further suggested that prize fighting was a reminder of the embarrassing inadequacies of England's previous system of policing. At best, local magistrates under the traditional authority had ignored prize fighting events, intimidated by the attending "Fancy". At worst, magistrates had themselves attended and even officiated at boxing matches.

In seemed that no amount of tampering with the rules would bring the sport within the range of what Victorian society perceived as "rational recreations"

$12 R$ v Davis, The Times, September 11, 1829.

13 See $R$ v Wilkinson, The Times, April 3, 1834.

14 M. Wiener, Men of Blood: Violence, Manliness and Criminal Justice in Victorian England (2004), p.49.

15 Colquhoun outlined his views to the Select Committee of the House of Commons on Policing in 1834, see IUP Series on British Parliamentary Papers, Crime and Punishment: Police (1968-1971), Vol.6, App.4, pp. 404-433.

16 J. Carter Wood, Violence and Crime in Nineteenth Century England: The Shadow of our Refinement (2004), p.75. 
in tune with the disciplined and regulated norms of that society. ${ }^{17}$ Boxing, as with many other folk-based sports, would have to subject itself to the "civilising process" in order to survive. ${ }^{18}$ Incrementally, and taking its lead from the institutional writers, the criminal law reflected these societal concerns.

\section{The Riot and Tumult of The Ring}

In Crown Cases (1762), Sir Michael Foster appeared well disposed to friendly exertions of cudgelling, fencing and trials of strength involving wrestling and sparring. These "manly diversions" were not unlawful because, according to Foster, "they intend to give, strength, skill and activity and may fit people for defence, public as well as personal in time of need." ${ }^{19}$ Equally, Foster was resolute in his view that "prize fighting and public boxing matches...can serve no valuable purpose but on the contrary encourage a sport of idleness and debauchery." 20 Prize fighting was taken to be associated with all manner of vice. It promoted gambling and was viewed as a social nuisance.

In 1822, for example, the owner of the "Tennis Court", a well-known boxing academy in London's Haymarket, took an action for libel "in his vocation as an exhibitor of sparring matches". ${ }^{21}$ The case centred on whether the plaintiff's exhibitions were illegal. Burrough $\mathrm{J}$ was of the opinion that they were:

"The chief object for which persons attend these exhibitions is to see and judge the comparative strength and skill of the parties, who may be afterwards matched as prize fighters...there can be no doubt that the skill acquired in these schools enables the combatants to destroy life... and it is notorious that persons assembled at these exhibitions engage in illegal bets on the issues of such encounters." 22

Three years later, in $R$ v Billingham, Savage and Skinner, Burrough J was arguing that prize fighting should be banned primarily on the ground that it promoted breaches of the peace:

"By law whatever is done in such an assembly by one, all present are equally liable for; which ought to make persons very careful. It cannot be disputed that all these fights are illegal, and no consent can make them legal, and all the country being present would not make them any less an offence. They are unlawful assemblies, and every one going to them is guilty of an offence." 23

17 Compare with the development of sports such as football, cricket and greyhound racing in R. Vorspan, "Rational Recreations and the Law: The Transformation of Popular Urban Leisure in Victorian England" (2000) 45 McGill L.J. 891.

18 N. Elias, The Civilizing Process (1994), at p.166.

19 Fost. 260.

20 ibid.

21 Hunt v Bell (1822) 1 Bing. 1, 130 E.R. 1.

22 ibid., at 5.

23 (1825) 2 Car. \& P. 234, 172 E.R. 106. 
In the case at hand, the defendants were indicted for a riot and an assault of a magistrate. The first and second-named defendants were the combatants. Skinner had been assisting in the organisation of the fight. He had objected to the magistrate's attempts to stop the fight and arrest the participants. The magistrate had then attempted to arrest Skinner, instigating a "general tumult" among the thousand-strong crowd, which had ended only with the "rescue" of Skinner and the magistrate's retreat.

A guilty verdict followed as it would in $R$ v Perkins. ${ }^{24}$ In Perkins, the combatants and their seconds were indicted on various charges of riot. Evidence emerged that Perkins had struck the first blow. Patteson J directed the jury to the effect that prize fighting was illegal because it was clearly a breach of the peace, thus, it was irrelevant as to who struck the first blow. All who were present, and again the estimate was that the crowd numbered over a thousand, were, according to the court, as guilty of riot as the principals. The jury passed a guilty verdict.

Similarly, in $R \vee$ Hargrave, ${ }^{25}$ the defendant, who had assisted in the promotion of a prizefight during which a fighter had died, was convicted of manslaughter and sentenced to fourteen years' transportation. $R \vee E d w a r d$ Murphy ${ }^{26}$ also concerned a charge of manslaughter directed upon a fighter's second. In that case, Murphy had attended a prizefight in support of his brother, who during the course of the bout had killed his opponent, Edward Thompson. A number of witnesses attested to the fact that Murphy had indeed attended the fight but that he had not assisted with the running or management of the fight. Accordingly, Murphy's defence was that he could in no way be considered to have actively aided and abetted in the death of Thompson. Nevertheless, Littledale J's direction to the jury was clear: "If the prisoner was at this fight, encouraging it by his presence, he is guilty of manslaughter, although he took no active part in it."

Littledale $\mathbf{J}$ also reminded the jury that if the death had occurred from violence unconnected with the fight itself, then the defendant could not be found guilty. The background to that direction is that the prizefights of the era were often interrupted by the surrounding mob. These invasions were usually of a tactical nature, instigated by supporters of the fighter who appeared to be struggling. The idea was that as attempts were made to clear the ring and push these supporters behind the roped-off area, the boxer in question would effectively be given an extended period in which to recover. There was evidence in this case that the defendant had been an integral part of an assembled "Irish mob" that had intervened in such a manner in order to protect "their man" from the advances of Thompson, who had clearly been the superior fighter. A verdict of guilty of manslaughter was returned and Murphy was sentenced to two months' hard labour.

Finally, on February 9, 1841, Daniel Herbert, a constable in the Bedfordshire rural police, attempted to put a halt to a prizefight at which there were over four hundred spectators. Herbert admitted that he had received a tip-off as to the fight's venue. On entering the roped-off area, Herbert stated that he had

24 (1831) 4 Car. \& P. 537, 172 E.R. 814.

25 (1831) 5 Car. \& P. 170, 172 E.R. 925.

26 (1833) 6 Car. \& P. 103, 172 E.R. 1164. 
observed two men "in fighting attitudes" both of whom he had attempted to arrest. The crowd prevented him from doing so, upon which the constable charged the defendant "in the Queen's name to aid and assist in the quelling of this riot." The defendant, Brown, had refused claiming that he had been charged with the care of the spectators' horses and carriages. In $R \mathrm{v}$ Brown, ${ }^{27}$ the Crown successfully prosecuted the defendant for refusing to assist a constable in the execution of his duty with Alderson B reminding the court that all prizefights were illegal as breaches of the peace, thus all persons engaging in them were punishable by law.

Overall, it is suggested that by 1838 the law on prize fighting was as unambiguous as Alderson B suggested: prize fights in their unacceptably riotous and unruly assembly equated to breaches of the peace. The determination with which the English courts sought to eliminate prize fighting was further evidenced in the manner in which they gradually extended liability beyond the combatants to include, as aides and abettors, the fight's organisers and spectators. In this, the courts took their lead, and were consistent with, the views expressed by the institutional writers. ${ }^{28}$ By the second half of the nineteenth century, enhanced police resources (individual constables would rarely be as isolated as Herbert was in Brown) not only increased the rate of prosecutions but also contributed to the emphasis in such actions switching from the indirect - unlawful assemblies and riot; towards the direct - assault. Baron Alderson had alluded to this approach in $\mathrm{R} \mathrm{v} H u n t,{ }^{29}$ where the defendants had been indicted on one count of riot and in another for affray as a result of a prize fight held in front of a large crowd off an isolated country lane. Alderson B, who four years earlier in Brown had been satisfied simpliciter to declare prizefights illegal as breaches of the peace now argued:

"It seems to me that there is no case against these men. As to the affray, it must occur in some public place, and this is to all intents and purposes a private one. As to riot, there must be some sort of resistance made to lawful authority to constitute it, some attempt to oppose the constables who are there to preserve peace. The case is nothing more than this: - Two persons choose to fight, and others look on, and the moment the officers present themselves, all parties quietly depart. The defendants may be indicted for an assault but nothing more."

In sum, by the latter half of the nineteenth century, it had become clear that the legality of the very nature of prize fighting, as opposed to its incidentals, was now being examined in the English courts. Notwithstanding that on conviction prize fighters often received little more than a token fine or short custodial sentence, the cumulative effect of increased police and judicial activity against the sport was beginning to take its toll. ${ }^{30}$ In addition, the situation in England was aggravated by the sport's increasingly corrupt

27 (1841) 1 Car. \& M. 314, 174 E.R. 522.

281 Hale P.C. 443-5, Fost. 260 and 1 East P.C. 270.

29 (1845) 1 C.C.C. 177.

$30 R$ v Case, The Times, March 15, 1830 and $R$ v Dawson, The Times, March 17, 1841 ; on conviction for manslaughter each defendant was fined one shilling. 
organisation. Prize fighting's commercial heart was about to be transplanted elsewhere.

\section{Boxing's New World}

The nature of the American sport is encapsulated in a bout between Ned Hammond and George Kensett held in New York on 14 October 1824. The sport was dominated by Irish (Hammond was a Dubliner) and English (Kensett was a Liverpudlian) fighters. The fight's original location, Coney Island, was typical in that it was, in relative and contemporary terms, a secluded yet accessible venue, in the same way as racecourses such as Ascot and Epsom proved popular with the London prize fighting fraternity. The bout eventually took place in Queens, once the party - combatants, seconds and spectators - had evaded a bayonet charge by infantry under the sheriff of Kings County. ${ }^{31}$

For the next decade or so, the American sporting press downplayed prize fighting's popularity. ${ }^{32}$ It was dismissed as a minority sport with a small ethnic base, which was held as nothing more than an excuse for working class, Anglo-Irish mobs to provoke each other or city authorities. ${ }^{33}$ Admittedly, American prize fighting remained a highly unregulated affair, though by the 1850s, a combination of the post-Famine Irish masses (a sympathetic and eager audience) and elite fighters from England (driven by the legal campaign against the sport) meant that it could no longer be ignored. The irregular but robust nature of American pugilism was epitomised in fighters such as John Ambrose "Yankee" Sullivan. Sullivan, who was born in Cork in 1813, established quite a reputation as a prizefighter, notably defeating the highly-rated William Bell on Hart's Island, NY for a stake of three hundred dollars in the summer of $1842 .{ }^{34}$

Shortly after the Bell fight, Sullivan assisted Christopher Lilly in a fight against Thomas McCoy, held near Hastings in the Hudson Valley, New York. McCoy received a terrible beating and died of his injuries. Subsequently, a grand jury indicted the promoters and the ring keepers, including Sullivan, on charges ranging from riot to manslaughter. ${ }^{35}$ The local authorities in Westchester County, clearly under pressure from their nearby city counterparts, set out to make an example of Sullivan. While most of the accused were fined, Sullivan was convicted of manslaughter and sentenced to two years' imprisonment. Ruggles $\mathrm{J}$, in a judgment that is clearly identifiable with the then English perspective on the sport, reiterated the institutional writers' view that prize fighting was a reprehensible activity because:

31 Reports of early prizefights can be found in The American Fistiana, which claimed to be the definitive history of the American ring. It was first published in 1849, enlarged in 1860 and again in 1873 by Robert DeWitt.

32 See the examples cited in J. Betts, "Sporting Journalism in Nineteenth Century America" (1953) 5 Amercian Quarterly 39 at 44.

33 See The American Fistiana (1860), n.31, pp.7-8, for an account of a fight between Jem Reed and Tom Burrett that degenerated into a full-scale riot on Hart's Island in 1835 .

34 The American Fistiana (1860), n.31, pp.10-13.

35 T. McDade, "Death in the Afternoon" (1970) 46 Westchester Historian 1. 
"A prizefight ... brings together a large assemblage of the idle, disorderly, vicious, dissolute people . . . you can readily perceive the influence which such assemblages are likely to exercise on the public peace, and morals, and taste ... The assemblage was in itself indictable as an unlawful one." 36

Despite receiving a gubernatorial pardon within six months, Sullivan was careful never to fight again in the state of New York. During the period 1838 to 1860 , a key distinction in the legal response to prize fighting in England and America, emerges. Prize fighting events while not eo nominee an offence at common law in England and the United States, were nevertheless punishable as a breach of the peace, assault and battery, riot or affray. However, the American prize fighting fraternity took advantage of the fact that not all states within the Union were consistently of that view. While English prize fighting title bouts could, at a push, be held in France or Ireland; in the United States, and particularly on the eastern coast, fighters could easily cross a nearby state line in order to fight. In short, during the period in question, American prizefighters evaded the law's grasp for longer simply because, in comparison to their English colleagues, there was more geographical and jurisdictional confusion in which to do so. For example, when Sullivan eventually lost his title to Tom Hyer in February 1849, the fight was fixed for Poole's Island in Chesapeake Bay mainly on the grounds that the island's jurisdictional status was a matter of dispute between the federal government and the Maryland authorities.

In 1860, prize fighting, in its bareknuckle tradition, had its last great event. The so-called "Championship of the World" between the English champion, Tom Sayers, and John C. Heenan held at Farnborough in Hampshire attracted an enormous crowd. ${ }^{37}$ The internationalism and success of the fight could not disguise the sport's decline. In the United States, the sport suffered badly in the 1860 s, partly due to the Civil War draft though mainly as a consequence of the sport's insidious corruption. ${ }^{38}$ In England, the legal campaign against the sport had now extended to prohibiting railway companies from hiring out trains to facilitate "prize fighting" excursions. ${ }^{39}$

Moreover, proponents of the sport in England knew that influential elements in society had begun to tire of the prize fighting spectacle and its associated tumults. As the foundation of the Football Association (1863) and the Rugby Football Union (1871) demonstrated, the Victorian policy on sport demanded institutional administration and codification. Similarly, Gorn notes that unlike other "shifty" sports of the Gilded Age, such as baseball and horse racing, prize fighting in the United States suffered because it failed to sanitise itself in the form of effective rules, regulations and sanctions. ${ }^{40}$ The drafting of the Queensberry Rules by John Graham Chambers in 1865 must

36 Reported in The New York Herald, November 28, 1842.

37 A. Lloyd, The Great Prize Fight (1977).

38 Gorn, n.5 at pp.172-178.

39 Regulation of Railways Act 1868 (31 \& 32 Vic., c.119). Specially chartered trains were an integral part of major prize fighting events; they facilitated much pre-fight gambling and, with the cooperation of private railway operators, permitted all to escape quickly once the event had taken place.

40 Gorn, n.5 at p.172. 
be seen in this context. The rules were a clear attempt to bring the sport within the contemporary definition of a respectable and legitimate leisure pursuit. In this, the rules not only promoted tightly regulated gloved bouts of fixed duration, they were also designed to appeal expressly to both the "gentleman" amateur and the law. ${ }^{41}$ The acceptance of the Queensberry Rules and a concomitant decline in bare fisted fighting did not take place immediately, or at least not as quickly as the authorities in England and the United States would have liked. In order to persuade the prize fighting fraternity that their future lay within the Queensberry code, the authorities once again resorted to an application of the criminal law.

\section{Criminal Activity or Sporting Pursuit?}

In England, the initial legal attack on prize fighting had focussed on the sport's associated evils of gambling, riot and tumult. By 1838, there was a change in emphasis. Prosecutions now included charges of mutual assault (or in the case of fatalities, manslaughter charges), while convictions for associated prize fighting activities also began to attract stiffer sentences. ${ }^{42}$ This was in line with the general policy to promote socially acceptable "manly diversions" to the detriment of more traditional and unruly fist fighting activities. However, as an 1860 article in the Law Times chided:

“. . . [w]here is the written or unwritten code which permits boxing with gloves, and prohibits boxing without gloves; which allows of fencing and the single-stick, but not of a permitted blow with the bare knuckles?...If prize fighting be illegal, let it be declared to be so by the Legislature. Otherwise let us fear the judge-made law, which seeks, perhaps to substitute only the dainty squeamishness of the present age for the coarse but masculine brutality of former times." ${ }^{43}$

The courts addressed the charge of "dainty squeamishness" by directing juries that a bout was lawful if it were an amicable contest or mere exhibition of skill in sparring but if the combatants intended to struggle in anger and fight until one was exhausted it was a criminal offence. Accordingly, it was for the jury to decide, on the basis of the presented evidence, whether the stated encounter was a sparring match (a legal and acceptable fighting contest) or a prizefight (viewed as an illegal and intolerable struggle). As the essentials of both versions of the sport remained very similar, this was an extremely difficult distinction to make. ${ }^{44}$ The introduction of the Queensberry Rules in 1865 would have helped, although it must be remembered that in contrast to the other major sports of the period, a credible governing authority did not exist in boxing to ensure that the code was

41 S. Shipley, "Boxing”, in Sport in Britain: A Social History (A. Mason ed., 1989), pp.78-115.

42 Wiener, n.14 at p.49. See $R$ v Lidstone, The Times, December 11, 1858, where on a manslaughter conviction, the surviving fighter was sentenced to six months' hard labour.

43 'Is Prize Fighting Legal?', The Law Times, April 28, 1860, p.75.

44 See N. Parpworth, "Boxing and Prize Fighting: The Indistinguishable Distinguished" (1994) 2 Sport and the Law Journal 5. 
uniformly applied. It would take almost a quarter of century before the Queensberry Rules could be said to have been truly accepted.

In the meantime, juries took a sympathetic view of any activity that could ostensibly be deemed a "fair fight". Consequently, acquittals in prizefight deaths remained more likely than in manslaughter charges taken as a whole..$^{45}$ Wiener observes that of the thirty men charged with manslaughter resulting from a prizefight at the Old Bailey in the period 1856-1875, thirteen were acquitted, and sentences for the convicted never exceeded six months. ${ }^{46}$ However, by the end of the 1870 s the authority of the Queensberry rules was beginning to settle and the distinction between that which was legitimate with the fist and that which was unacceptable, had become more readily identifiable. For example, in $\mathrm{R}$ v $\mathrm{Orton}^{47}$ the defendants had been convicted at trial for unlawfully assembling for the purpose of a prizefight. The Court of Criminal Appeal dismissed the appeal, affirming the trial judge's direction to the jury:

"If it were a mere exhibition of skill in sparring [it was not unlawful]; but that if the parties met intending to fight till one gave in from exhaustion or injury received, it was a breach of the law and a prizefight, whether the combatants fought with gloves or not." 48

After an exhaustive review of the facts, including an examination of the bloodied gloves used by the combatants, the Orton jury had held that, although the appearance was of an organised boxing match, such was the severity and intensity of the blows that the nature of the fight clearly went beyond that which would normally be expected of a gloved sparring exhibition of fixed duration. In legal argument, reference was made to $R \mathrm{v}$ Young. ${ }^{49}$ In that case, a boxer had been charged with manslaughter as a result of a sparring exhibition held in an indoor arena. During the course of the bout, Young's opponent had fallen against a ring post and died. Bramwell $\mathrm{B}$, in directions that ultimately led to a verdict of not guilty, had difficulty in seeing what was unlawful with the matter at hand primarily on the ground that the fight had taken place in private rooms, there being no breach of the peace:

"No doubt if death ensued from a fight, independent of its taking place for money, it would be manslaughter, because a fight was a dangerous thing and likely to kill; but the medical witness here had stated that this sparring with gloves was not dangerous, and not a thing likely to kill . . . however . . . supposing there was no danger in the original encounter, and the men fought on until they were in such a state of exhaustion

45 A broader criminological perspective on the concept of a "fair fight" and the rituals associated with prize fighting can be found in C. Conley, The Unwritten Law: Criminal Justice in Victorian Kent (1991), ch.2.

46 Wiener, n.18 at p.50. Note also the remarkable acquittal in $R \mathrm{v}$ Walker, The Times, March 7, 1876 when the jury disregarded the defence counsel's purported admission of his client's guilt.

47 (1878) 14 C.C.C. 226

48 ibid., 227.

49 (1866) 10 C.C.C. 371. 
that it was probable they would fall, and fall dangerously, and if death ensued from that, it might amount to manslaughter." ${ }^{50}$

Two years earlier, the Supreme Court of Massachusetts had taken a similar approach. In Commonwealth v Collberg, ${ }^{51}$ the defendants were charged with assault and battery. At trial, the defendants rejected the charges on the ground that they had mutually consented to the bout in question. Furthermore, they claimed that the contest, which had taken place in a secluded spot in front of a small and peaceful crowd, was nothing more than an amicable and athletic test of strength and agility. In contrast, the prosecution noted that the bout had been instigated as a result of a prior and hostile verbal altercation between the parties, that the parties intended to do each other bodily harm and had fought until one of the parties (Collberg) was at a "standstill" and a "good deal bruised". The trial judge, Lord J, instructed the jury:

"If the defendants were simply engaged in a wrestling match, that being a lawful sport, they could not be convicted of an assault and battery; but if by mutual agreement between themselves ... [they] . . . went to a retired sport for the purpose of fighting with each other ... with a view to ascertain by a trial of their skill in fighting which was the best man, and there engaged in a fight, each endeavouring to and actually doing all the physical injury in his power to the other . . . each may properly be convicted of assault and battery upon the other, although the whole was done by mutual arrangement ... and without anger on the part of either against the other." 52

On appeal, the Supreme Court of Massachusetts, then one of the most influential courts in the United States, was of the opinion that the instructions were an accurate representation of the law. The implicit agreement between the American and English courts at this point is reflected in the fact that Lord $\mathrm{J}$ 's instructions were entirely similar to those given in the English case of $R \mathrm{v}$ Ward. ${ }^{53}$ In that case, the prisoner had been tried and convicted for the manslaughter of a man whom he had killed during a fight, notwithstanding the largely uncontested evidence that the fight had been conducted fairly and was little more than a public trial of skill in boxing. A subsequent appeal was rejected with the court affirming the trial judge's view that the premeditated and hostile nature of such encounters should be discouraged.

This focus on both the nature and operation of a prizefight is fundamental to the understanding of the Court of Crown Cases Reserved's celebrated decision in $R \vee$ Coney. ${ }^{54}$ In that case, an eight-three majority rejected the "easy and summary" mode of suppressing prize fighting by targeting those who supported it..$^{55}$ The majority held that mere voluntary presence at a prizefight should not be translated into a charge of aiding and abetting a

50 ibid., 373.

51 (1876) 119 Mass. 350; 20 Am Rep 328.

52 ibid., 119 Mass. 350 at 353-54.

53 (1872) 12 C.C.C. 123

54 (1882) 8 Q.B.D. 534.

55 ibid., 550 per Stephen J. 
criminal activity. ${ }^{56}$ As a preliminary issue, the court had been unanimous in holding that prize fighting was a criminal activity. Mathew $\mathbf{J}$ was succinct: "no consent can render that innocent which is in fact dangerous . . . The fists of a trained pugilist are dangerous weapons which they are not at liberty to use against each other." 57 Stephen J took the traditional view that "prizefights are injurious to the public both because it is against the public interest that the lives and health of the combatants should be endangered by blows, and because prizefights are disorderly exhibitions, mischievous on many grounds." ${ }^{58}$ Cave J was more expansive:

". . . [a] blow struck in anger, or which is likely or intended to do corporal harm, is an assault, but that a blow struck in sport, and not likely, nor intended to cause bodily harm, is not an assault, and that, an assault being a breach of the peace and unlawful, the consent of the person struck is immaterial. If this view is correct a blow struck in a prizefight is clearly an assault; but playing with single sticks or wrestling do not involve an assault; nor does boxing in the ordinary way, and not with the ferocity and severe punishment to the boxers deposed to in Reg v Orton." 59

Hawkins J concurred, warning the boxing fraternity that even under what he termed "the colour of a friendly encounter", if the parties had as their object the intent to beat each other until one of them was exhausted or subjugated by that force, and so engage in conflict likely to end in a breach of the peace, the parties remained exposed to a prosecution in assault. ${ }^{60}$

With the Coney judgment interpreting legitimate fighting contests in such a restrictive manner, it is difficult to see how, in its wake, any competitive, antagonistic and professional boxing contest could have been justified at law. ${ }^{61}$ The Court of Crown Cases Reserved appeared, impliedly at least, to be promoting amateur exhibitions or sparring contests of an athletic purpose only and it is noteworthy that at this time amateur boxing was flourishing in Britain. ${ }^{62}$ In 1880, the Amateur Boxing Association had been founded and in the following year, it was sufficiently established to be in a position to hold the first official national amateur championships from a feeder of local competitions.

Similarly, in the United States, various state jurisdictions were taking the position that only "manly diversions" of a very limited fighting scope would

56 Littledale J's direction to the jury in $R$ v Murphy (1833) 6 Car. \& P. 103, 172 E.R. 1164 rejected. See Coney, at 543 per Cave J; at 550 per Stephen J; at 552 per Lopes J; at 557 per Hawkins J; at 561 per Huddleston B; at 562 per Mainsty J. In contrast, see Coney at 548 per Mathew J; at 563-566 per Pollock B and Lord Coleridge who remarked at 569: "The brutalising effect of prizefights are chiefly due to the crowd who resort to them."

57 ibid., Coney, 547.

58 ibid., 549

59 Coney, 539.

60 ibid., 554

61 Note Lord Mustill's comments in $R$ v Brown [1993] 2 WLR 556, 590-592.

62 N. Tranter, Sport, Economy and Society in Britain, 1750-1914 (1998), at p.19. 
be permitted. In State v Burnham (1884), ${ }^{63}$ the Supreme Court of Vermont, in affirming the conviction of two prizefighters charged with breaching the peace, held:

"It is true ... that sparring or boxing with gloves manufactured for that purpose, as conducted and engaged in ordinary athletic sports, is not unlawful, nor in breach of the peace ... But such pugilistic exercise may be abused and carried beyond the limits of healthful and lawful exercise and sport. It may be conducted as to create a breach of the peace. It may even degenerate into a prizefight." ${ }^{\prime 64}$

Moreover, at this time a number of anti-prize fighting statutes emerged, crystallising the distinction between "boxing in the ordinary way" and illegitimate fighting contests. ${ }^{65}$ As early as 1849 , the Commonwealth of Massachusetts had enacted a statute dedicated to the proscription of the sport. ${ }^{66}$ Section one of the Act declared that every person who "by previous appointment" met another person to engage in a fight would be punished. Section two took care to provide that those present at such a fight - "as an aid, second or surgeon or promoter" - would also be punished. The provision was interpreted liberally in that it was not necessary, in order to maintain an indictment under the provision, to prove that the fight was for a prize or reward. ${ }^{67}$ Neither did it have to be proven that the agreement to fight took place in the jurisdiction nor at a distinct time and place from the actual bout. ${ }^{68}$

Prize fighting first received the dedicated attention of the legislature in the state of New York by the enactment in 1858 of a statute entitled: "An Act to prevent prizefights and fights among game animals." ${ }^{69}$ The following year saw the enactment of dedicated legislation in the form of, "An Act to prevent and punish prizefights." 70 Subsequently, section 458 of the Penal Code of the State of New York, which on conviction carried a maximum punishment of one year in jail and/or a fine of $\$ 250$, would read:

"A person who, within this State, engages in, instigates, aids, encourages, or does any act to further a contention or fight without weapons between two or more persons, or a fight commonly called a ring or prizefight, either within or without this State, or who sends or publishes a challenge or acceptance of the challenge for such a contention or fight, or carries or delivers such a challenge or acceptance, or trains or assists any person in training or preparing for such a contest or fight, is guilty of a misdemeanour."

63 (1884) 56 Vt. 445, 48 Am. Rep. 801.

64 ibid., 56 Vt. $445,448$.

65 E. Million, "The Enforceability of Prize Fight Statutes" (1937) 27 Ky.L.J. 152.

66 Mass. Laws 1849, c.49.

67 Commonwealth v Welsh and Mitchell (1856) 73 Mass. 324.

68 Commonwealth $v$ O'Baldwin (1869) 103 Mass. 210 and Commonwealth v Barrett. (1871) 108 Mass. 302.

69 N.Y. Laws 1858 , c.98.

70 N.Y. Laws 1859 , c.37. 
Further west, section 6888 of the Revised Statutes of the State of Ohio provided, "whoever engages as principal in any prizefight shall be imprisoned in the penitentiary for not more than ten years nor less than one year." On 25 February 1891, David Seville fought Arthur Majesty at the Nelsonville Athletic Club, Ohio. Majesty died of his injuries. Seville was indicted and convicted of a violation of section 6888. In Seville v State,$^{71}$ the defendant appealed to the Supreme Court of Ohio, principally on the ground that the trial judge had erred in sustaining the prosecution's objection to the testimony offered by an expert witness on the fundamental differences between prize fighting and boxing, the latter, it was claimed, having taken place on this occasion.

Williams $\mathbf{J}$, in dismissing the appeal, reminded the court that the purpose of the statute was clear: "to suppress all prize fighting, because of its brutality, and consequent danger to human life, as well as the demoralising and pernicious effects it has on the good order and well being of society." 72 Williams J agreed with the trial judge that the term "prizefight" should be given its ordinary meaning under the statute, accordingly: "The question for the jury to decide was, whether this combat was a prizefight; not what the Queensberry Rules, or any other rules called it, nor what name those accustomed to such combats, have given it. What was it in plain English?"73

Subsequently, the Supreme Courts of Arkansas, ${ }^{74}$ Colorado, ${ }^{75}$ Delaware, ${ }^{76}$ Indiana, ${ }^{77}$ Kansas, ${ }^{78}$ Kentucky, ${ }^{79}$ Michigan, ${ }^{80}$ Oklahoma $^{81}$ and Wisconsin ${ }^{82}$ would also interpret the term prize fighting in a strict manner, equating it to any pugilistic encounter or boxing match for a stake or reward. Some commentators suggest that the stated legal developments "devastated" the commercial viability of the bare fisted sport in America. ${ }^{83}$ Yet, in the same year that the Supreme Court of Vermont was tending toward a more restrictive definition of prize fighting, the most important fight in the history of modern boxing was about to occur. On September 7, 1892, at the New Orleans Olympic Club, John L. Sullivan, prize fighting's undisputed champion, fought James J. Corbett. That Sullivan lost is of minor interest because the symbolism of fight - its history, its organisation and its aftermath - are of fundamental significance to the law's evolving attitude towards the sport.

1 (1892) 49 Ohio St. 117, 30 N.E. 621.

ibid., 49 Ohio St. 131.

3 ibid., 136-137.

74 Magness v Isgrig (1920) 145 Ark. 232, 225 S.W. 332.

75 People v Corbett (1922) 72 Colo. 117, 209 P. 808.

76 State v Gregory (1928) 34 Del. 115, 143 A. 458.

77 State v Patton (1902) 59 Ind. 248, 64 N.E. 850.

78 State v Purtell (1896) 56 Kan. 479, 43 P. 782.

79 Commonwealth of Kentucky v McGovern (1903) 116 Ky. 212, 75 S.W. 261.

80 People v Taylor (1893) 96 Mich. 576, 56 N.W. 27.

81 Teeters v Frost et ux. (1930) 145 Okla. 273, 292 P. 356, 71 A.L.R. 179.

82 Parmentier v McGinnis (1914) 157 Wis. 596, 147 N.W. 1007.

83 M. Isenberg, John L. Sullivan and His America (1994), at p.81 and J. Sammons, Beyond the Ring: The Role of Boxing in American Society (1990), at p.6. 


\section{Sullivan vs. Corbett}

Much of John L. Sullivan's career was spent ducking, weaving and evading the law's grasp. The law never landed a knockout punch, though cumulatively it did enough to make Sullivan change tactics and with that the bare knuckle prizefight was abandoned and the sport of boxing emerged. The law was the primary reason for Sullivan's inability to pursue his profession in the state of his birth. Not only were the authorities in Massachusetts reasonably proficient in implementing the state's anti-prize fighting provisions, they also, through decisions such as Collberg, demonstrated a willingness to indict prizefighters for assault and battery.

Sullivan sought respite in the commercial heart of American prize fighting New York; but the law followed. Section 458 of the Penal Code of the State of New York ensured that prizefighters had to undertake some subterfuge in order to partake in bouts. In 1883, the then Mayor of New York, Franklin Edson, launched a campaign of "moral" reform, part of which was a drive to eradicate prize fighting. Central to that operation was the much-publicised stoppage by the police of the Sullivan vs. Charlie Mitchell bout at Madison Square Garden on May 14, 1883. Similarly, on November 18, 1884, the police brought a bout between Sullivan and Alf Greenfield to a premature halt on the grounds that the participants were clearly breaching the terms of a State Supreme Court order that had permitted an exhibition of sparring only in circumstances where "the blows were to have no relation to the injury or exhaustion of either party." ${ }^{84}$

In the immediate aftermath of that fight, the combatants were arrested and charged under section 458. The subsequent trial, held on December 17, 1884, was simply a piece of theatre. The jury, awestruck by Sullivan's presence (and most likely bribed), returned a unanimous verdict of not guilty. The jury took less than eight minutes to hold that what had taken place was a mere exhibition and not a contest for physical supremacy. Sullivan now knew that if he couched his bouts in the language, circumstance and rules of gloved boxing or sparring exhibitions, the law as then stated in New York (and most states in the Union) would have little practical impact on the sport. From then on, only the most extreme cases of primitive, bare fisted prize fighting would fall foul of the New York statute. ${ }^{85}$

Accordingly, Sullivan, and all the leading American prizefighters, became increasingly attracted to Queensberry-regulated bouts. The advantages were manifold: they resulted in an air of legitimacy gathering round the sport; they attracted lower levels of physical risk; they increasing a boxer's commercial capacity by permitting him to fight more often. The new regulations also facilitated indoor, purpose-built stages or plinths, superseding the established tradition that a prize fighting ring should only be staked in turf. That particular initiative advanced the sport's progress in a number of ways. For

84 Sullivan's plea in front of Barrett J at State Supreme Court received significant coverage in The New York Times, November 16-18, 1884.

85 Contrast People v Floss (1889) 7 N.Y.S. 504, where the event was held to be a mere exhibition between two women fighters and People v Finucan (1903) 80 N.Y.S. 929, where the promoter of a bare fisted prizefight fought under the London Prize Ring Rules was convicted. 
the emerging middle classes, it meant that boxing events could now be held in exclusive gentlemen's clubs. Equally, the working class could enjoy regular bouts at the local hall. Although indoor arenas made it easier for the local police to patrol events, promoters could now exercise stricter control over the collection of the admission price.

The benefits of adopting a sanitised version of the sport were clearly demonstrated to John L. Sullivan in the embarrassing aftermath of his bare fisted fight against Charlie Mitchell in France in March 1888. On July 8, 1889 , Sullivan would be goaded into his final bare fisted fight, when he defended his title against Jake Kilrain near Richburg, Mississippi. ${ }^{86}$ Sullivan emerged triumphant but it was a pyrrhic victory. Although, much to the embarrassment of the state authorities, the fight had managed to take place, the crowd was relatively small, numbering no more than three thousand. ${ }^{87}$ Furthermore, the state of Mississippi was sufficiently moved to indict both fighters.

In Sullivan v The State of Mississippi ${ }^{88}$ Sullivan was convicted on a violation state's anti-prize fighting statute. Although an appeal was upheld on the grounds that the indictment in question was fatally defective, Sullivan could not sustain the expenses associated with such litigation, and his stake for defeating Kilrain was lost in costs. Sullivan vowed never again to fight under the old bare knuckle rules and it is within that context that the historic 1892 fight against Corbett in New Orleans must be seen.

Even though Sullivan vs. Corbett was a sporting and commercial success for the sport of prize fighting, the law quickly reasserted its authority. ${ }^{89}$ In State v Olympic Club, ${ }^{90}$ a review of the activities being promoted by the New Orleans Olympic Club, then the centre of boxing promotions in the United States, held that what was occurring were not simply licensed gloved contests predicated on skill and athleticism but bouts fought to a bloody finish underwritten by significant gambling wagers. ${ }^{91}$ Similar decisions, clamping down on the scope of exhibitions that could be held by athletic clubs, followed in several hitherto benign jurisdictions. ${ }^{92}$ American prize fighting did then what it always had done and searched for jurisdictions that were more sympathetic. For a while, it found refuge in the relaxed legal climate of the West. Carson City in Nevada, for example, was the host for the Bob Fitzsimmons vs. James J. Corbett heavyweight title fight on March

86 See J. Cox, "The Great Fight: Mr. Jake vs. John L. Sullivan" (1984) 15 The Smithsonian 153.

87 See W. Adams, "New Orleans as the National Centre of Boxing" (1956) 39 Louisiana Historical Quarterly 92 and D. Somers, The Rise of Sports in New Orelans, 1850-1900 (1972), p.170.

88 (1890) 67 Miss. 346, 7 So. 275.

89 See State v Olympic Club (1894) 46 La. Ann. 935, 15 So. 190 where an unsuccessful attempt to shut down the New Orleans Olympic Club revealed that the Club had recorded a profit of more than $\$ 50,000$ from the proceeds of the Sullivan vs. Corbett fight.

90 (1895) 47 La. Ann 1095, 17 So. 599.

91 Contrary to the anti-prize fighting statute passed by the General Assembly of the State of Louisiana on June 25, 1890, (La. Laws 1890, c.25).

92 See, for example, Ohio: In re Athletic Clubs (1896) 5 Ohio S. \& C.P. Dec. 696 and State ex rel. Attorney General v Hobart (1901) 11 Ohio. Dec. 166. 
17, 1897, while the California Athletic Club established a solid reputation for prize fighting in San Francisco in the 1880s and 1890s. However, this "cat and mouse" between the authorities and the prize fighting fraternity would soon exhaust both parties.

It must be remembered that participation in or the aiding and abetting of a prize fighting was rarely more than a misdemeanour in the various anti-prize fighting statutes of the era. ${ }^{93}$ Moreover, it is arguable that prize fighting had, through the adoption of the Queensberry Rules, sanitised itself to such an extent that those very provisions effectively proscribed a sport that no longer existed. Implementing the proscription of a popular and now seemingly safe sport was seen as a waste of policing resources and of limited moral or political expediency. Equally, the prize fighting fraternity knew that the move West was not sustainable. They were clearly willing to submit to further regulation if that was what was required to survive. All these factors would crystallise in New York City.

\section{The New York Model}

More so than rival cities such as New Orleans and San Francisco, New York had a concentrated and interested sporting population. It was home to the national sporting press. It had venues as diverse as Coney Island and Madison Square Garden and its location best facilitated the promotion of international bouts. In 1896, the Horton Laws amended section 458 of the Penal Code by exempting from its operation sparring exhibitions with gloves held in buildings owned or leased by a domestic incorporated athletic association. ${ }^{94}$ The intention was that professional pugilism would be legalised so long as such gloved bouts would take place for the pleasure of members only in clubs incorporated under the Membership Corporations Law of the State of New York. ${ }^{95}$

This legislative initiative was broadly in line with the shift in public opinion towards a sport that was seen to have evolved hugely in light of its eventual acceptance of the Queensberry Rules. ${ }^{96}$ The trend in favour of the sport had been identifiable in a jury's acquittal of Bob Fitzsimmons in a manslaughter trial resulting from the death of his opponent in a public sparring exhibition held in Syracuse on November 16, 1894. Fitzsimmons was one of the stars of the emerging sport. World middleweight champion from 1891 to 1894 , he ultimately became the world heavyweight champion on defeating James J. Corbett in 1897. As with all professional prizefighters of the era, Fitzsimmons's main income came from exhibitions of which the Syracuse event was typical. Shortly into that contest, Fitzsimmons struck his sparring partner a single, concussive blow to the side of the face. The opponent died five hours later without regaining consciousness.

93 See, for example, La. Laws 1890, c.25, s.1; Miss. Acts 1882, p 142; N.Y. Laws 1859, c.37, s. 1 .

94 N.Y. Laws 1896, c. 37

95 N.Y. Laws 1895 , c.559.

96 S. Reiss, "In the Ring and Out: Professional Boxing in New York, 1896-1920" in Sport in America: New Historical Perspectives (D. Spivey, ed., 1985), pp.95-128. 
In People v Fitzsimmons, ${ }^{97}$ the presiding judge's instructions to the jury specifically acknowledged Fitzsimmons's defence - that he had been engaged in a lawful contest the exclusive nature of which was an exhibition of the skills of sparring, and not in the misdemeanour prohibited by section 458 - by reminding the jury that "in any athletic contest, exhibiting powers of skill, there is necessarily involved an element of danger."98 The jury found the defendant not guilty and the acquittal seems to suggest that by the mid-1890s the New York public viewed the practices of the Queensberry code as a reasonable restriction on the sport's previous inherent excesses. In fact, the Horton Laws, introduced shortly afterwards, should probably be seen as a legislative recognition of that perspective on pugilism.

The provision was effectively a statutory recognition of the Queensberry Rules and to the extent that it monitored the participants' conduct and safety within the ring, the scheme was quite successful. In recognition, championship boxing returned to New York where, on 9 June 1899, James J. Jeffries defeated Fitzsimmons in a world heavyweight title fight. However, the Horton Laws' administration of that which occurred "outside" the ring was less successful and the prize fighting fraternity, in particular its gambling element, could not resist the exploitation of a loophole within the provision. Under the scheme, private member clubs were not permitted to grant public access nor were they allowed to levy an admission fee to the general public, however, this was circumvented by the practice that membership of a club would be granted to anyone purchasing a ticket for the upcoming fight. ${ }^{99}$

In 1900, an outrageous gambling scam would lead to the repeal of the Horton Laws. ${ }^{100}$ On 30 August 1900, Charles "The Real" McCoy fought the exheavyweight champion, James J Corbett. McCoy, who won more than half of his 107 fights by knockout, was expected to win easily but he threw the fight, as ordered to by a gambling syndicate of which he was an associate member. By 1901, New York had again lost much of its attraction for the fight game particularly at the higher end of the scale, and few championship fights occurred in the state during the first decade of the new century.

The popularity of the sport in New York City, and the futility of attempting to maintain a total proscription on all forms of organised fist fighting, meant that a compromise was inevitable. That compromise manifested itself in the enactment of the Frawley Laws in 1911. ${ }^{101}$ That scheme established a New York State Athletic Commission ("NYSAC") and gave all contests licensed by that commission an express exemption from the applicable provisions of the New York Penal Code. In addition, the Frawley Laws mandated certain minimum medical safeguards and authorised the NYSAC to regulate the general health and safety concerns of the profession. ${ }^{102}$ The authority of the

97 (1895) 34 N.Y.S. 1102. See W. Hechter, "The Criminal Law and Violence in Sport" (1976-7) 19 Crim. L.Q. 425 at 442.

98 ibid., 34 N.Y.S. 1107.

99 See People v Johnson (1903) 49 N.Y.S. 382

100 N.Y. Laws 1900, c.270.

101 N.Y. Laws 1911, c.779.

102 L. Laufer, "Uniform Health and Safety Standards for Professional Boxing" (1984) 15 Columbia Human Rights Law Review 259 at 270. 
NYASC was enhanced when in 1914 the State Supreme Court upheld its decision to refuse to grant a license to Bob Fitzsimmons on the grounds of age (he was over fifty years old) and physical condition (he had by then fought over three hundred competitive bouts). ${ }^{103}$ By 1917, the Frawley Laws had been repealed as Governor Whitman reacted in disgust to the death of a fighter in an event held in the state capital, Albany.

Three years later, professional boxing in its modern form was finally and fully legalised in the state of New York by the Walker Laws of 1920. ${ }^{104}$ The Walker Laws reconstituted the NYSAC with the power to implement a rigorous licensing code regulating all aspects of the sport. In this, the Walker Laws made no distinction between prize fighting and professional boxing. The legality of an event was determined not by the nature of the fight but whether it had taken place under the regulatory control of the NYASC. ${ }^{105}$ It is probably an exaggeration to attribute the remarkable advancement of professional boxing in the 1920 s solely to the introduction of the Walker Laws, nevertheless, they did have a profound impact. The scheme was soon followed throughout the United States. In 1923, for example, Pennsylvania created an Athletics Commission modelled on the Walker Laws. Two years later, California legalised professional boxing under a similar scheme, after a statewide referendum. In 1926 it was Illinois's turn, while in April 1927, Colorado formed a boxing commission. By 1933, states as diverse as Washington and Texas had adopted statutory schemes similar to that of New York. ${ }^{106}$ In England, the predominance of the NYSAC was acknowledged by the fact that when the British Boxing Board of Control ("BBBC") - the sport's private regulatory agency in the UK - was set up in 1929, it largely accepted the New York classification of the different weight categories for fighters.

\section{Late Victorian Boxiana}

As various jurisdictions within the US moved towards a statute-based compromise, English prize fighting was also being treated more sympathetically in the post-Coney era of the 1880s. Codification and enhanced administrative control of the sport throughout that decade was rewarded with decreasing police and judicial interest in the sport. The criminal law reflected that retreat in the sense that any death or injury consequent to ordinary or incidental participation in boxing was seen as excusable so long as the authorities were satisfied that the sport did not tend towards a breach of the peace, that its rules and practices remained reasonable, were consented to by all engaged and were not likely to induce serious injury or to end life. ${ }^{107}$ In short, once prize fighting was seen to have undertaken a process of rational regularisation, in line with many other traditional sports of the Victorian era, its legal future was seen as secure.

103 Fitzsimmons v The NYSAC (1914) 146 N.Y.S. 117, affirmed 147 N.Y.S. 1111.

104 N.Y. Laws 1920, c.912.

105 See the discussion in People ex rel. Weiner v Barr (1928) 228 N.Y.S. 192.

106 P. Millspaugh, "The Federal Regulation of Professional Boxing" (1994) 19 Seton Hall Legislative Journal 33 at 40-42.

107 See also $R$ v Bradshaw (1878) 14 C.C.C. 83 and $R$ v Moore [1898] 14 T.L.R. 229 , cases concerning injuries and deaths in football. 
The impact of this implicit compromise quickly became evident. In the 1890 s and early 1900s the National Sporting Club ("NSC") governed the professional code in Britain. A number of fatalities occurred in NSCsponsored boxing events, most notably in December 1897 when the Chicagoborn Jimmy Barry killed Walter Croot in a world bantamweight championship bout. In the aftermath of the fight, five men, including prominent members of the NSC, were charged with manslaughter. In a decision that resonates with the acquittal of Bob Fitzsimmons in New York two years previously, the authorities subsequently dropped all charges in recognition of the proper administration of the sport by the NSC. ${ }^{108}$

It is worth reiterating that the self-regulatory freedom granted to boxing in England must be seen in light of the pervading view that the sport's associated risks had now been minimised to acceptable levels. Pointedly, an article in The Lancet dismissed a number of deaths in NSC-administered fights, attributing them to apoplexy and nervous tension. ${ }^{109} \mathrm{In}$ fact, the compromise that emerged in the 1880 s - based on the careful self-regulation of a risky but on balance safe sport - is encapsulated in the contributor's view that the events at the NSC were generally "of such a high class nature that no really violent blow was received on either side." In sum, by the beginning of the twentieth century the settled view in Britain was that the law would have little need to further investigate that affairs and conduct of boxing, and for a large part, the sport has since avoided the law's critical gaze.

\section{Conclusion}

The policy on sport, such as it existed in nineteenth century England, was preoccupied with the metamorphosis of traditional sports into events as regulated and controlled as the factory whistle. It was felt that these rational recreations would help divert the working class during their increased leisure periods and, ideally, transform them into efficient, disciplined and "muscular" Christians. In that context, the concerted effort to rationalise, legitimise and distinguish boxing from its prize fighting roots must be seen as an outstanding example of the social and sporting engineering policies of the era. A similar pattern is identifiable in America's Gilded Age. This article has suggested that in both countries the criminal law was the principal tool used in that task.

By the 1920s, professional boxing was the most commercialised and truly global of sports with the heavyweight bout between America's Jack Dempsey and the French war hero George Carpentier on July 2, 1921 becoming the first sporting event to gross one million dollars in gate receipts alone. In the United States, boxing was by then regulated on strict statutory basis - state schemes that had their origins in the anti-prize fighting statutes of the mid-nineteenth century. That process of legislative intervention continues to this day with the US Congress currently considering a bill to

108 G. Deghy, Noble and Manly: The History of the National Sporting Club (1956) at p.147 and K. Sheard, "Brutal and Degrading": The Medical Profession and Boxing, 1838-1984” (1998) 15 International Journal of the History of Sport 74 at 78 .

109 The Lancet, May 11, 1901, p.1366. 
create a Federal Boxing Commission. In the UK, boxing continues to selfregulate under the auspices of the British Boxing Board of Control, an organisation that traces its origins to the Pelican Club established in the 1880s. It is also within that decade that the legality of the sport in English law can be found. In what this article has termed the "post-Coney" compromise, the legality of a BBBC-licensed boxing match is based on the presumption that it is not a prizefight tending towards a breach of the peace, it is adequately regulated, it is relatively safe with its social utility as a competitive aspect of a recognised sport justifying (if not entirely explaining) its exemption from the ordinary threshold of consent in criminal law. 